\title{
Thiophene-Phenylene/Naphthalene-Based Step-Ladder Copolymers
}

\author{
TORSTEN W. BÜNNAGEL, ${ }^{1}$ BENJAMIN S. NEHLS, ${ }^{1}$ FRANK GALBRECHT, ${ }^{1}$ KRISTINA SCHOTTLER, \\ CHRISTOF J. KUDLA, ${ }^{1}$ MARKUS VOLK, ${ }^{1}$ JOÃO PINA, ${ }^{2}$ JOÃO S. SEIXAS de Melo, ${ }^{2}$ \\ HUGH D. BURROWS, ${ }^{2}$ ULLRICH SCHERF ${ }^{1}$ \\ ${ }^{1}$ Bergische Universität Wuppertal, Institute for Polymertechnology and Macromolecular Chemistry, \\ D-42097 Wuppertal, Germany \\ ${ }^{2}$ University of Coimbra, Department of Chemistry, 3004-535 Coimbra, Portugal
}

Received 17 July 2008; accepted 21 August 2008

DOI: 10.1002 / pola.23039

Published online in Wiley InterScience (www.interscience.wiley.com).

\begin{abstract}
A series of step-ladder copolymers based on thiophene-phenylene-thiophene SL1-SL3 and thiophene-naphthylene-thiophene SL4 repeat units with varying lengths of the oligothiophene segment has been designed and synthesized via a microwave-assisted Stille-type cross-coupling reaction followed by a polymeranalogous cyclization reaction. The optical properties of the step-ladder copolymers have been investigated in detail, in particular at low temperature and in the solidstate. (ㅇ 2008 Wiley Periodicals, Inc. J Polym Sci Part A: Polym Chem 46: 7342-7353, 2008
\end{abstract}

Keywords: conjugated polymers; fluorescence; polycondensation; synthesis; UV-vis; X-ray

\section{INTRODUCTION}

Phenylene- and thiophene-based materials belong to the most extensively studied classes of conjugated molecules for use in organic electronic devices such as light-emitting diodes, ${ }^{1,2}$ polymer lasers, ${ }^{3}$ field-effect transistors, ${ }^{4}$ and polymer solar cells $^{5,6}$ Unsubstituted oligomers of a certain length are generally completely insoluble in organic solvents and require vacuum deposition. However, for large area devices, solution-processable materials are needed..$^{7}$ The introduction of solubilizing side-chains can significantly increase the solubility, and therefore the processability, but

Additional Supporting Information may be found in the online version of this article.

Correspondence to: T. W. Bünnagel, Cambridge Display Technology Ltd., Greenwich House, Madingley Road, Madingley Rise, Cambridge, CB4 0TX, UK (E-mail: torsten@ buennagel.net)

Journal of Polymer Science: Part A: Polymer Chemistry, Vol. 46, 7342-7353 (2008) (๑) 2008 Wiley Periodicals, Inc. may also induce steric hindrance resulting in a mutual distortion of the building blocks of the single-stranded molecules. This distortion often reduces the $\pi$-conjugation along the backbone and changes the optical and electronic properties of the polymer. To overcome or at least minimize the problem of reduced $\pi$-interactions much effort was devoted to rigidify the backbone partially or completely by the introduction of additional interring bridges, which may furthermore bear the necessary solubilizing side-chains. ${ }^{8}$ Because a soluble ladder-type poly(para-phenylene) (LPPP) was described in 1991 by Scherf and Müllen ${ }^{9}$ much effort has been devoted to the tuning of the polymers properties and processability. Various types of bridges have been realized. For example, in addition to the original methylene bridges, ethane, or carbonyl bridges have been described as well as heteroatom bridges containing nitrogen or sulfur atoms, respectively. ${ }^{10-24}$

Within this contribution the synthesis of a series of novel, partly rigidified, thiophene- 

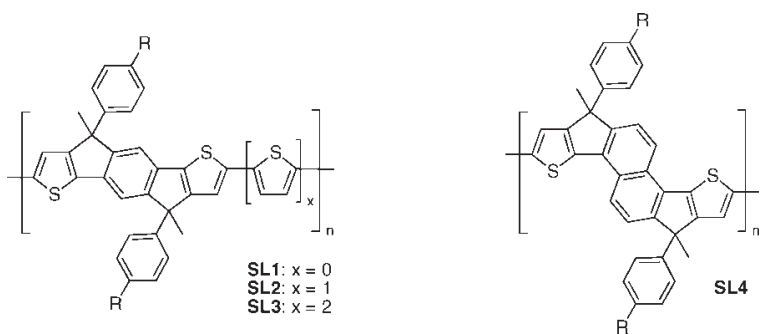

Figure 1. Structure of thiophene-phenylene-thiophene (SL1-SL3) and thiophene-naphthylene-thiophene (SL4)-based step-ladder polymers

phenylene-thiophene, and thiophene-naphthylene-thiophene-based step-ladder copolymers is described. These alternating copolymers contain a central ladder-type building block that was synthesized in a ring closure reaction similar to the LPPP synthesis that was combined with oligothiophene segments of different length (Fig. 1).

\section{THIOPHENE-PHENYLENE-THIOPHENE AND THIOPHENE-NAPHTHYLENE-THIOPHENE STEP LADDER COPOLYMERS-RESULTS AND DISCUSSION}

The polymeric intermediates toward the desired step-ladder copolymers SL1 and SL2, the polyke- tones PK1 and PK2, as shown in Scheme 1, were synthesized in a microwave-assisted Stille-type cross-coupling reaction from the terephthalophenone monomer $\mathbf{1}$ and the corresponding bis(trimethyl)stannyl oligothiophenes utilizing $\mathrm{PdCl}_{2}$ (dppf) as catalyst. ${ }^{24,25}$ The resulting single-stranded polyketones PK1 and PK2 were purified by Soxhlet extraction with ethanol to remove low molecular weight fractions and yielded the polyketones in 44 and $47 \%$ yield, respectively. The next synthetic step was a polymer-analogous transformation of the keto groups into tertiary alcohols by reaction with lithium organyls (here: methyl lithium). ${ }^{26}$ The progress of the conversion was monitored by IR-spectroscopy via the disappearance of the carbonyl band. The final Friedel-Crafts-type ring closure was achieved by addition of an excess of $\mathrm{BF}_{3} \cdot \mathrm{Et}_{2} \mathrm{O}$ to a solution of the polyalcohol in dichloromethane. ${ }^{27}$ This ring closure sequence allows for the introduction of a broad variety of substituents ranging from alkyl to alkylphenyl side groups via addition of different lithium organyls. To remove low molecular weight fractions all step-ladder polymers were again extracted with ethanol and subsequently precipitated into methanol to afford the step-ladder copolymers SL1 and SL2 in yields of 76 and $71 \%$, respectively. The polymers were soluble in many
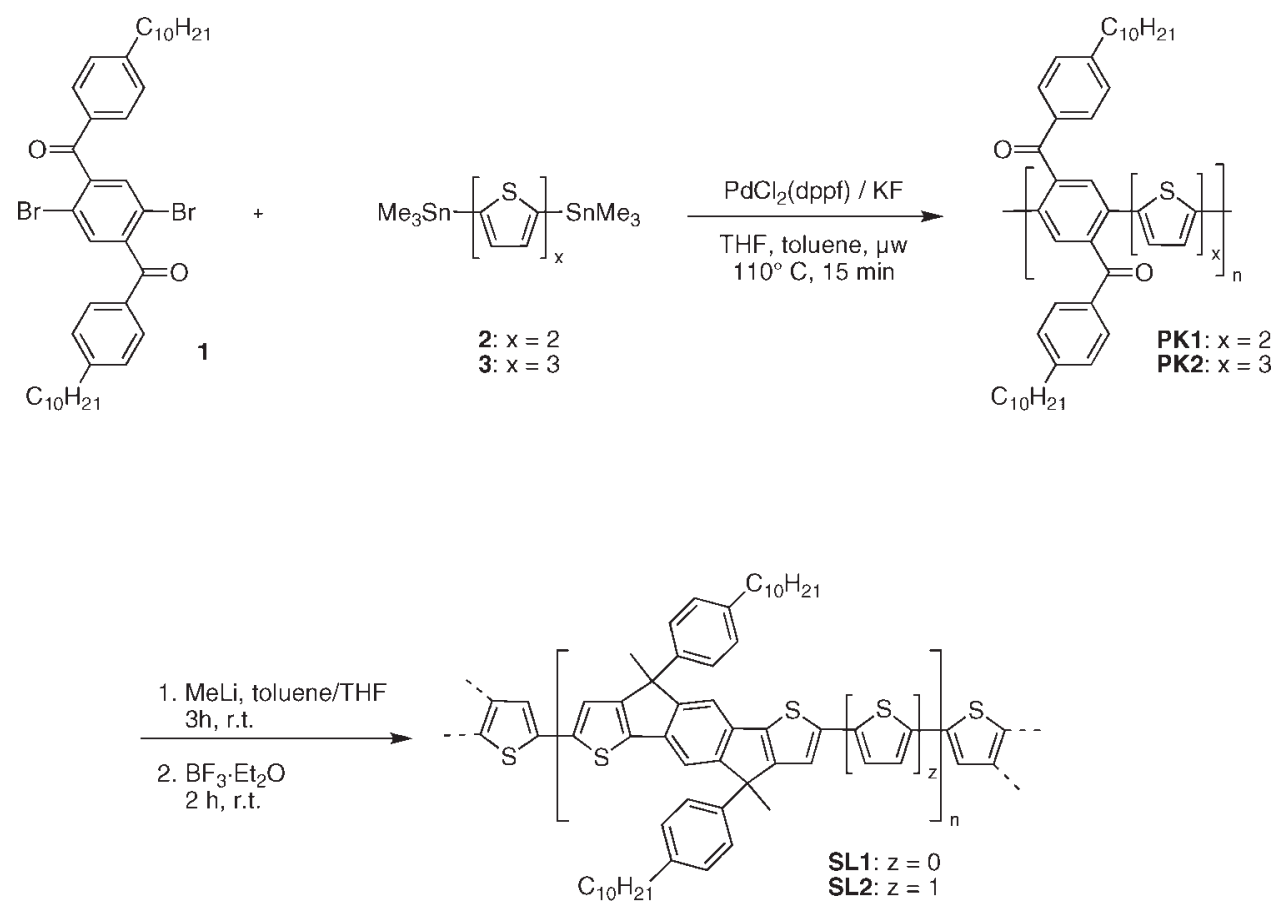

Scheme 1. Synthesis of the step-ladder copolymers SL1 and SL2 in a microwaveassisted Stille-type cross-coupling reaction and subsequent polymer-analogous cyclization. 
Table 1. Yields and Molecular Weights of the Polyketones PK1, PK2, PK3, and PK4 and Step-Ladder-Type Copolymers SL1, SL2, SL3, and SL4 (GPC Analyses Performed on Solutions of the Copolymers in THF with PS Calibration)

\begin{tabular}{lcccc}
\hline Polymer & Yield [\%] & $M_{\mathrm{n}}(\mathrm{g} / \mathrm{mol})$ & $M_{\mathrm{w}}(\mathrm{g} / \mathrm{mol})$ & $\mathrm{PD}$ \\
\hline PK1 & 44 & 10,400 & 29,000 & 2.8 \\
PK2 & 47 & 14,800 & 53,100 & 3.6 \\
PK3 & 52 & 12,600 & 40,200 & 3.2 \\
PK4 & 49 & 12,800 & 30,900 & 2.4 \\
SL1 & 76 & 12,000 & 24,000 & 2.0 \\
SL2 & 71 & 16,200 & 47,000 & 2.9 \\
SL3 & 72 & 14,200 & 44,000 & 3.1 \\
SL4 & 82 & 13,500 & 28,400 & 2.1 \\
\hline
\end{tabular}

organic solvents like toluene, chloroform or dichloromethane thus allowing a full spectroscopic characterization. GPC analysis revealed $M_{\mathrm{n}}$ values of $12,000 \mathrm{~g} / \mathrm{mol}(\mathrm{PD}=2.0)$ and 16,200 $\mathrm{g} / \mathrm{mol}(\mathrm{PD}=2.9)$ for copolymers SL1 and SL2, respectively (Table 1). The copolymers were fully characterized by ${ }^{1} \mathrm{H} /{ }^{13} \mathrm{C}-\mathrm{NMR}$ spectroscopy. In the ${ }^{13} \mathrm{C}-\mathrm{NMR}$ spectrum of the polyketone precursor PK1 the carbon resonance of the carbonyl group was observed at $\partial=196.7 \mathrm{ppm}$. Upon cyclization to SL1, the disappearance of the keto resonance and the appearance of a signal at $\partial=53.2 \mathrm{ppm}$ assigned to the newly formed quarternary carbon of the methylene bridge proved the complete for- mation of the step-ladder structure. Similar features could be observed for the copolymers PK2/ SL2 with corresponding carbon signals at $\partial=$ $194.2 \mathrm{ppm}$ (PK2) and $\partial=54.1 \mathrm{ppm}$ (SL2), respectively. Because of the very low solubility of unsubstituted $2,2^{\prime}: 5^{\prime}, 2^{\prime \prime}: 5^{\prime \prime}, 2^{\prime \prime \prime}$-quaterthiophene, generation of the appropriate distannylated derivative was unfeasible. Therefore, an alternate synthetic route towards the step-ladder copolymer bearing four thiophene rings per repeat unit was established. The synthesis of monomer 4 started from the terephthalophenone monomer $\mathbf{1}$, which was reacted with 2-(tributyl)stannyl thiophene following a microwave-assisted Stille-type coupling protocol as described previously. ${ }^{28}$ Bromination of the monomer with NBS gave the dibromo monomer $4,{ }^{29}$ which was copolymerized with bis (trimethyl)stannyl bithiophene $\mathbf{2}$ to the corresponding polyketone PK3. Reduction and cyclization with (i) methyl lithium and (ii) $\mathrm{BF}_{3} \cdot \mathrm{Et}_{2} \mathrm{O}$, respectively, as described before yielded the stepladder copolymer SL3 (Scheme 2). ${ }^{27}$ After Soxhlet extraction with ethanol, a GPC analysis revealed an $M_{\mathrm{n}}$ of $14,200 \mathrm{~g} / \mathrm{mol}(\mathrm{PD}=3.1)$ for the copolymer SL3. The copolymer was further characterized by ${ }^{1} \mathrm{H} /{ }^{13} \mathrm{C}-\mathrm{NMR}$ spectroscopy. For the synthesis of the thiophene-naphthylene-thiophene step ladder copolymer SL4 the naphthylene-based diketo monomer $\mathbf{5}^{30}$ was coupled with the distannylated bithiophene monomer $\mathbf{2}$ in a similar
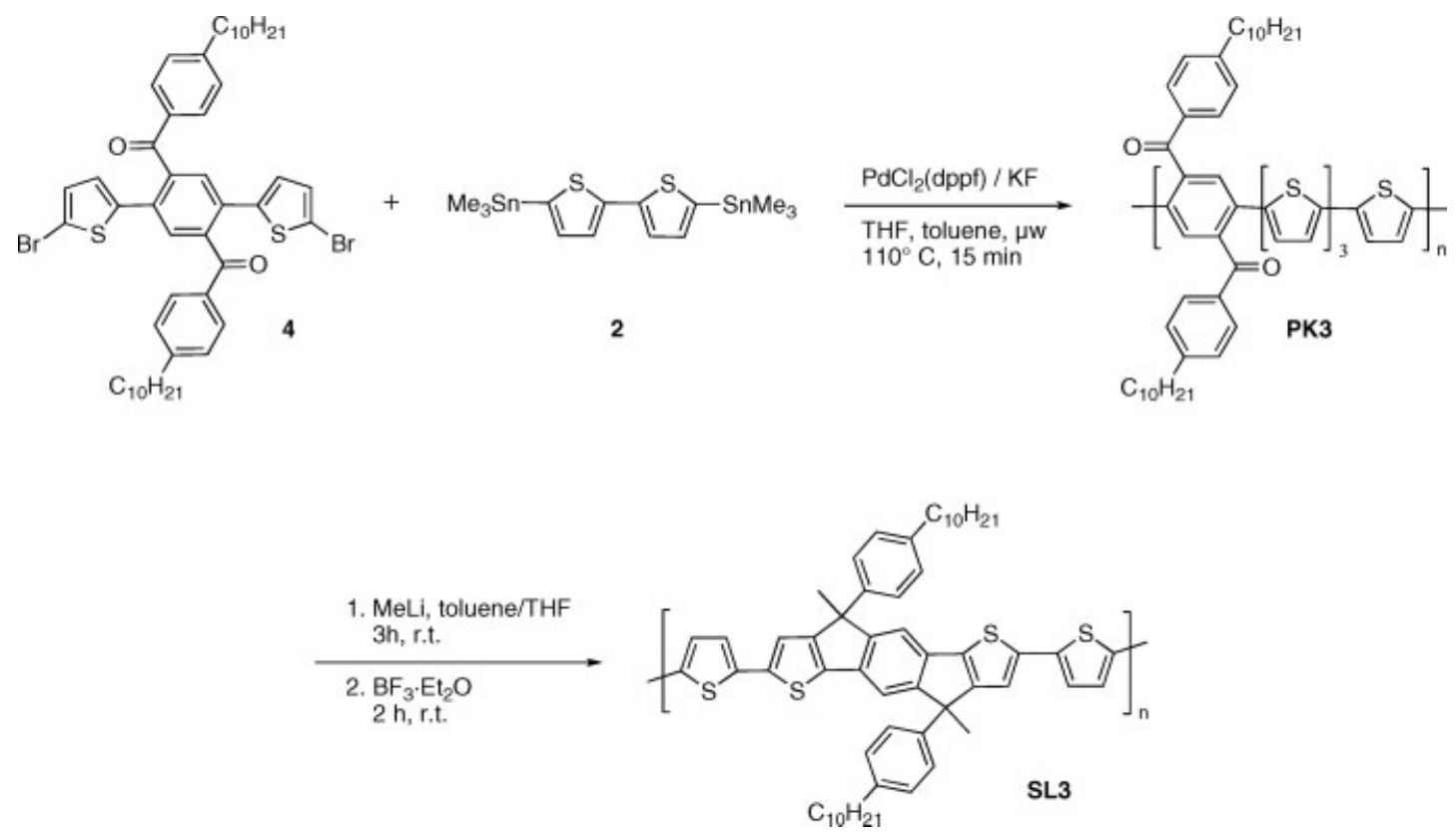

Scheme 2. Synthesis of the step-ladder copolymer SL3 in a microwave-assisted Stille-type cross-coupling reaction and subsequent polymer-analogous cyclization. 


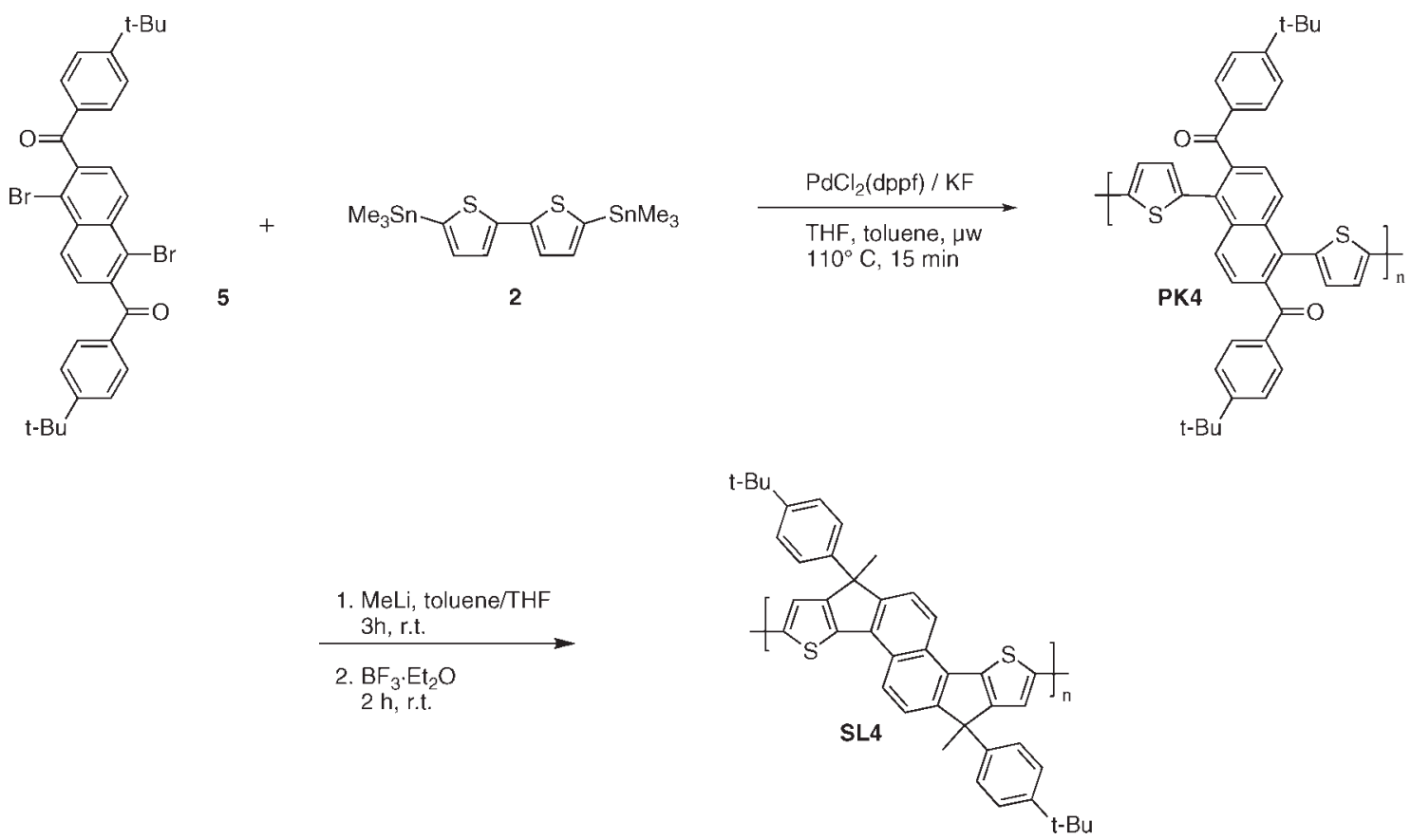

Scheme 3. Synthesis of step-ladder copolymer SL4 in a microwave-assisted Stilletype cross-coupling reaction and subsequent polymer-analogous cyclization.

microwave-assisted Stille-type cross-coupling reaction (Scheme 3). ${ }^{24,25}$ The reaction yielded the single-stranded precursor polymer PK4, which was purified by Soxhlet extraction with ethanol to remove low molecular weight fractions (yield: $49 \%$ after precipitation into methanol). Subsequently, the polyketone was applied to the already described polymer-analogous reaction sequence including (1) reduction with methyl lithium and (2) Friedel-Crafts-type ring-closure with an excess of $\mathrm{BF}_{3}\left(\mathrm{Et}_{2} \mathrm{O}\right.$ in dichloromethane. ${ }^{27}$ Again, the progress of the transformation was monitored by IR and NMR spectroscopy. After a final purification of the step-ladder copolymer SL4 by Soxhlet extraction with ethanol and reprecipitation from chloroform into methanol the copolymer SL4 was afforded in a yield of $82 \%$. An $M_{\mathrm{n}}$ of $13,500 \mathrm{~g} / \mathrm{mol}(\mathrm{PD}=2.1$ ) was confirmed by GPC analysis and the polymer further characterized by ${ }^{1} \mathrm{H}$ and ${ }^{13} \mathrm{C}$-NMR spectroscopy.

The UV-vis absorption spectra of the copolymers SL1, SL2 and SL3 in dilute toluene solution at room temperature are shown in Figure 2 and summarized in Table 2. The UV-vis spectrum of SL1 shows a long wavelength absorption band peaking at $480 \mathrm{~nm}$ with a shoulder at $523 \mathrm{~nm}$ and a steep absorption edge, consistent with the presence of a weakly distorted backbone structure. The incorporation of additional thiophene rings between the step-ladder subunits leads to a $25 \mathrm{~nm}$ red-shift of the absorption maximum for SL2 and a $28 \mathrm{~nm}$ red-shift for SL3, respectively. The bathochromic shift in SL2 when compared to copolymer SL1 reflects the lower band gap energy of (poly)thiophenes in comparison to (poly)phenylenes. However, a further increase of the length of the oligothiophene segment (when going from SL2 to SL3) causes only a minor additional change of the absorption characteristics. The room temperature photoluminescence (PL) emission spectra of the novel step-ladder copolymers again exhibit the highest energy PL for copolymer SL1, with a maximum at $562 \mathrm{~nm}$ and a vibronic side-band at $600 \mathrm{~nm}$. The copolymers SL2 and SL3 show a slight red-shift of the PL maxima (7 and $9 \mathrm{~nm}$, respectively) and slightly better resolved vibronic side-bands. As already discussed for the absorption spectra, also the PL spectra of the two copolymers with the elongated oligothiophene segments do not show significant differences. Therefore, it is expected that a further elongation of the oligothiophene segments will not lead to significant changes of the optical spectra. Upon lowering the temperature to $77 \mathrm{~K}$ the absorption spectra become more structured with well-resolved 0-1 and, in case of copolymer SL1, also $0-2$ progressions. The solid-state absorption spectra of thin films of the copolymers display a 


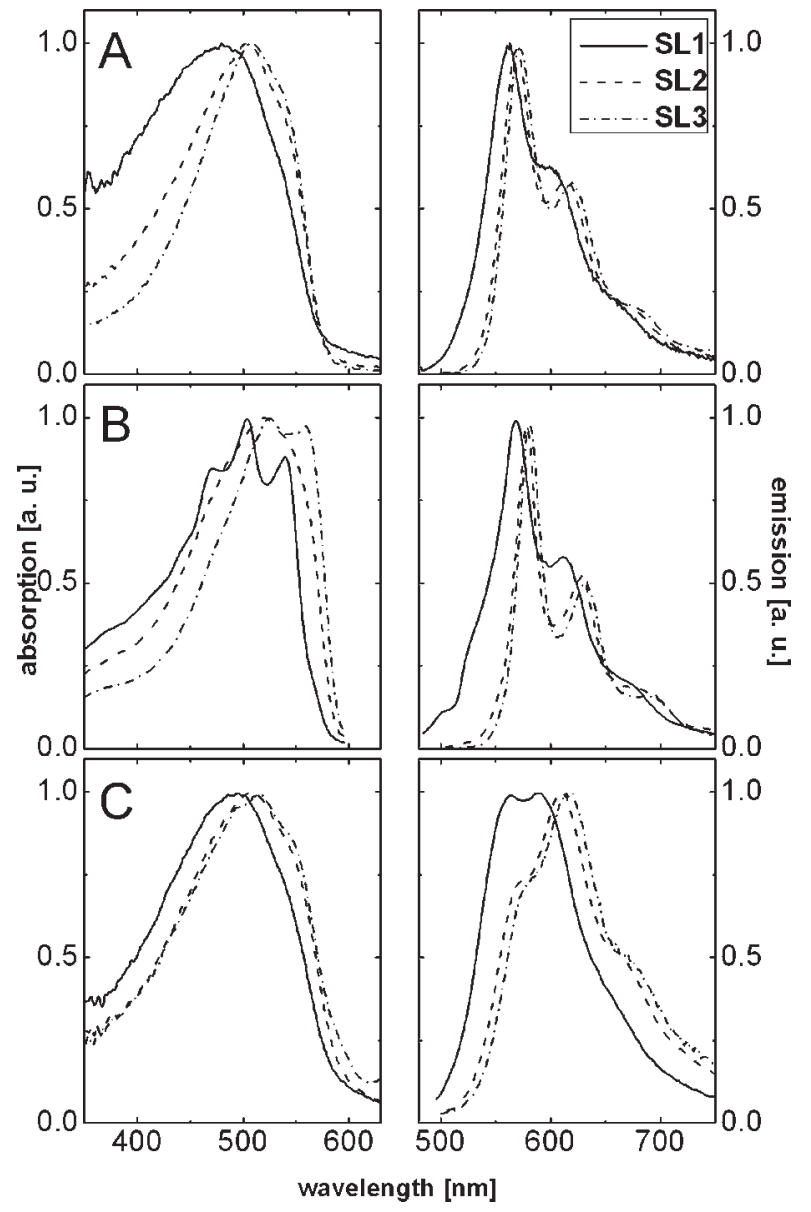

Figure 2. Absorption and photoluminescence (PL) emission spectra of the copolymers SL1, SL2, and SL3 in dilute toluene solution at room temperature $(\mathrm{A}, 293 \mathrm{~K})$, at low temperature $(\mathrm{B}, 77 \mathrm{~K})$, and as thin films (C).

noticeable broadening of the absorption band. The maxima of the PL solid-state emission spectra experience a slight hypsochromic shift of 10-12 nm for all copolymers when compared with low temperature data. This finding can be related to a more rigid structure at low temperature. The thin film PL spectra show only small bathochromic shifts when compared with the spectra in dilute solutions at room temperature $(298 \mathrm{~K})$. This implies that the copolymers in the solid state only show a low degree of interchain order. The amount of interchain order, leading to characteristic interchain $\pi$-interactions, is assumed to be responsible for the frequently observed red shifts of the optical spectra of conjugated polymers, especially oligothiophenes, in the solid state. The low intensity of the $0-0$ PL transitions of the copolymers SL1, SL2, and SL3 in the solid state is likely to be caused by self-absorption effects. The UV-vis absorption spectrum of the 1,5-naphthylene-based step-ladder copolymer SL4 in toluene solution at room temperature shows an absorption maximum at $482 \mathrm{~nm}$ (Fig. 3 and Table 3). Copolymer SL4 displays a more structured and narrower long wavelength absorption band when compared to copolymer SL1 with its significantly broadened absorption band. This result might be caused by an ongoing aggregation of the less soluble copolymer SL1 in toluene. Upon cooling to $77 \mathrm{~K}$ both absorption spectra become clearly structured and well-resolved $0-0,0-1$, and $0-2$ transitions are visible. A distinct blue shift of 15 $\mathrm{nm}$ could be observed for copolymer SL4 in relation to copolymer SL1. This finding can be rationalized by an increase of the energy difference between the benzoid (ground state) and quinoid (excited state) resonance structures when switching from 1,4-phenylene to 1,5-naphthylene leading to an increased excitation energy for SL4. The thin films absorption spectra of the two copolymers display less structured and broad absorption bands. The PL emission spectrum of the 1,5-naphthylene-based copolymer SL4 in dilute toluene solution displays a similar spectral shape in relation to its 1,4-phenylene-based counterpart SL1 apart from the blue-shift of the emission maximum of SL4 of $\sim 30 \mathrm{~nm}$. At lower temperature $(77 \mathrm{~K})$ again an improved resolution of the vibronic progressions due to an increased molecular order is observed. Copolymer SL4 shows well-resolved solid state PL emission bands with the $0-0$

Table 2. Spectroscopic Data of the Step-Ladder-Type Copolymers SL1, SL2, and SL3 in Toluene Solution at Room Temperature (293 K) and Low Temperature ( $77 \mathrm{~K})$, as well as in the Solid State (Thin Film)

\begin{tabular}{lcccccc}
\hline & $\begin{array}{c}\lambda_{\max }^{\mathrm{abs}}(\mathrm{nm}) \\
\text { Polymer }\end{array}$ & $\begin{array}{c}\lambda_{\max }^{\mathrm{abs}}(\mathrm{nm}) \\
77 \mathrm{~K}\end{array}$ & $\begin{array}{c}\lambda_{\max }^{\mathrm{abs}}(\mathrm{nm}) \\
\text { Film }\end{array}$ & $\begin{array}{c}\lambda_{\max }^{\mathrm{abs}}(\mathrm{nm}) \\
293 \mathrm{~K}\end{array}$ & $\begin{array}{c}\lambda_{\max }^{\mathrm{abs}}(\mathrm{nm}) \\
77 \mathrm{~K}\end{array}$ & $\begin{array}{c}\lambda_{\max }^{\mathrm{abs}}(\mathrm{nm}) \\
\text { Film }\end{array}$ \\
\hline SL1 & 480 & $470,505,540$ & 495 & 562,600 & 569,612 & 563,590 \\
SL2 & 505 & 520 & 510 & 569,615 & 578,627 & 576,610 \\
SL3 & 508 & 525,558 & 515 & 572,620 & 580,630 & 581,615 \\
\hline
\end{tabular}

The italicized wavelengths are the maxima with the highest intensity. 


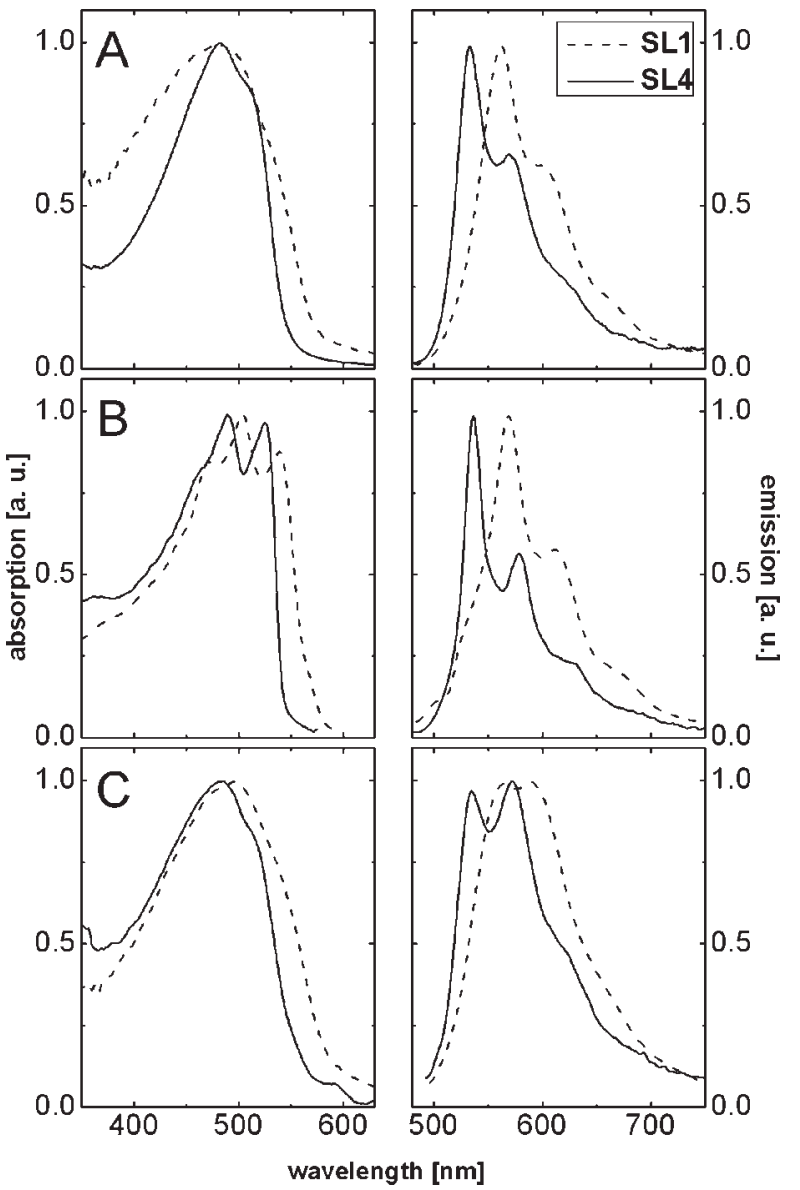

Figure 3. Absorption and PL emission spectra of the copolymers SL1 and SL4 in dilute toluene solution at room temperature (A, $293 \mathrm{~K})$, at low temperature $(\mathrm{B}, 77 \mathrm{~K})$, and as thin films $(\mathrm{C})$.

emission at 535 and its first vibronic progression at $572 \mathrm{~nm}$. The $0-0$ emission is significantly reduced due to self-absorption effects.

\section{SYNTHESIS AND CHARACTERIZATION OF A MODEL COMPOUND}

To gain a detailed insight into the molecular structure of the bridged bis(2-thienyl)benzene repeat units of the copolymers SL1, SL2, and SL3, synthesis and characterization of a related model compound was carried out. Scheme 4 depicts the synthesis of the dithienyl-substituted step-ladder thiophene-benzene-thiophene model compound. Diethyl 2,5-dibromoterephthalate 6 was reacted with 2.5 equiv. of $2,2^{\prime}$-bithio-phene-5pinacol boronate $\mathbf{7}$ utilizing $\mathrm{Pd}\left(\mathrm{PPh}_{3}\right)_{4}$ as catalyst and $\mathrm{K}_{2} \mathrm{CO}_{3}$ as base in a microwave assisted Suzuki-type cross-coupling reaction yielding the diketo compound 8 in $76 \%$ yield. $^{28}$ The intramolecular cyclization towards the model compound 10 was achieved by addition of methyl lithium and applying the $\mathrm{BF}_{3} \cdot \mathrm{Et}_{2} \mathrm{O}$-catalyzed ring closure reaction as described previously. ${ }^{27}$ Figure 4 shows the UV-vis absorption spectrum of the open-chain precursor 9 as well as of the cyclized model compound $\mathbf{1 0}$ in dilute chloroform solution. The cyclization of 9-10 is accompanied by a distinct redshift of the optical spectra. The precursor $\mathbf{9}$ shows a featureless long-wavelength absorption band peaking at $389 \mathrm{~nm}$, whereas upon ring-closure the absorption maximum is red-shifted to $424 \mathrm{~nm}$. Furthermore, 10 displays a much steeper absorption edge and better resolved vibronic side-bands due to the increased rigidity of the molecule. The corresponding PL spectrum of $\mathbf{1 0}$ exhibits two well-resolved PL peaks for the $0-0$ and $0-1$ transitions at 475 and $502 \mathrm{~nm}$, respectively, as well as a shoulder at $523 \mathrm{~nm}$ for the $0-2$ transition. The molecular structure of model compound $\mathbf{1 0}$ was also investigated by X-ray single crystal analysis. Figure 5 shows the planarity of the $\pi$-conjugated core segment that is bridged by two $\mathrm{sp}^{3}$ carbons. The four methyl side-groups are positioned orthogonal to the molecular plane. The attached thiophene substituents exhibit a slight out-of-plane twist of $20.05^{\circ}$ relative to the planar core segment suggesting that the copolymers SL1, SL2, SL3, and SL4 should also exhibit a similar weak distortion of the individual segments. The relatively small distortion is similar to the situation in unsubstituted oligo(para-phenylene)s (distortion angle: $\left.\sim 19^{\circ}\right){ }^{30}$ In contrast, a higher distortion

Table 3. Spectroscopic Data of the Step-Ladder-Type Copolymers $\mathbf{1 1}$ and $\mathbf{2 9}$ in Toluene Solution at Room Temperature $(293 \mathrm{~K})$ and at Low Temperature $(77 \mathrm{~K})$, as well as in the Solid State (Thin Film)

\begin{tabular}{|c|c|c|c|c|c|c|}
\hline Polymer & $\begin{array}{c}\lambda_{\max }^{\mathrm{Abs}}(\mathrm{nm}) \\
293 \mathrm{~K}\end{array}$ & $\begin{array}{c}\lambda_{\max }^{\mathrm{abs}}(\mathrm{nm}) \\
77 \mathrm{~K}\end{array}$ & $\begin{array}{c}\lambda_{\max }^{\mathrm{abs}}(\mathrm{nm}) \\
\text { Film }\end{array}$ & $\begin{array}{c}\lambda_{\max }^{\text {Fluo }}(\mathrm{nm}) \\
293 \mathrm{~K}\end{array}$ & $\begin{array}{c}\lambda_{\max }^{\text {Fluo }}(\mathrm{nm}) \\
77 \mathrm{~K}\end{array}$ & $\begin{array}{c}\lambda_{\max }^{\text {Fluo }}(\mathrm{nm}) \\
\text { Film }\end{array}$ \\
\hline SL4 & 482 & 490,525 & 485 & 533,570 & 536,577 & 535,572 \\
\hline SL1 & 480 & $470,505,540$ & 495 & 562,600 & 569,612 & 563,590 \\
\hline
\end{tabular}

The italicized wavelengths are the absorption and PL emission maxima with the highest intensity. 
<smiles>COC(=O)c1cc(Br)c(C(=O)O[Na])cc1Br</smiles><smiles>CCc1ccc(-c2ccc(B3OC(C)(C)C(C)(C)O3)s2)s1</smiles>

7

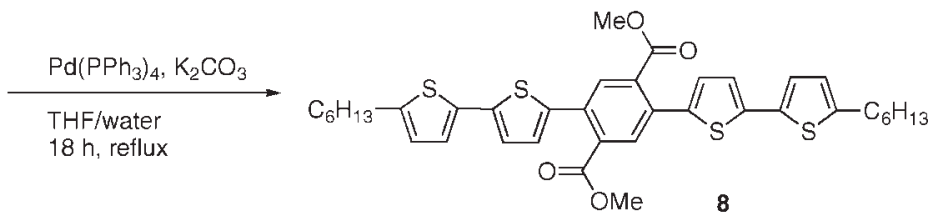
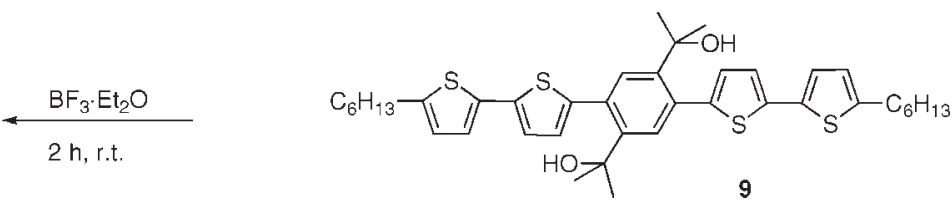

Scheme 4. Synthetic route towards the model compound 10.

angle is observed in regioregular poly(3-hexylthiophene) (P3HT, $\sim 30^{\circ}$ ). ${ }^{31,32}$ The weak distortion in oligomer $\mathbf{1 0}$ and the corresponding copolymers SL1, SL2, SL3, and SL4 should allow a sufficient conjugative interaction along the oligomer and copolymer backbones. Within the unit cell of the model compound $\mathbf{1 0}$ some intermolecular $\pi$-interaction between the planarized oligomer molecules occurs (shortest distance between the molecular planes: $4.2 \AA$ ). It can be concluded that the copolymers SL1, SL2, SL3, and SL4 should also allow some interchain $\pi$ - $\pi$-interactions.

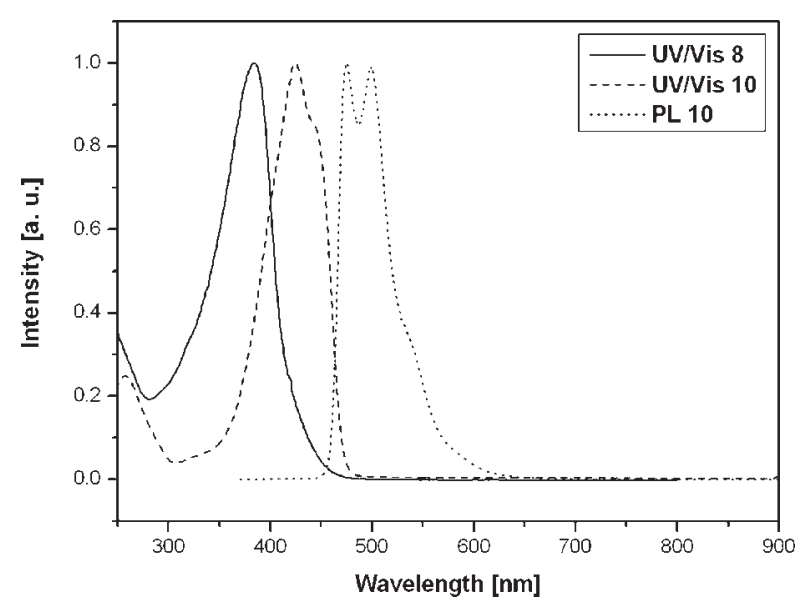

Figure 4. UV-vis absorption spectra of 8 and model compound $\mathbf{1 0}$ in dilute chloroform solution; as well as the PL spectrum of $\mathbf{1 0}$ in dilute chloroform solution (excitation wavelength: $445 \mathrm{~nm}$ ).

\section{CONCLUSIONS}

A series of thiophene-phenylene-thiophene and thiophene-naphthylene-thiophene-based stepladder copolymers with varying lengths of the oligothiophene segment has been synthesized in Stille-type cross-coupling reactions to give single-stranded precursor polymers followed by a polymer-analogous cyclization sequence. The increased energy difference between benzoid and quinoid resonance structures for the 1,5-naphthylene-based copolymer leads to a $15-30 \mathrm{~nm}$ blue shift of its absorption and emission spectra (both in dilute solution at different temperature and in the solid state). The optical spectra were recorded both in dilute solution at different temperatures and in the solid state and revealed a spectral red-

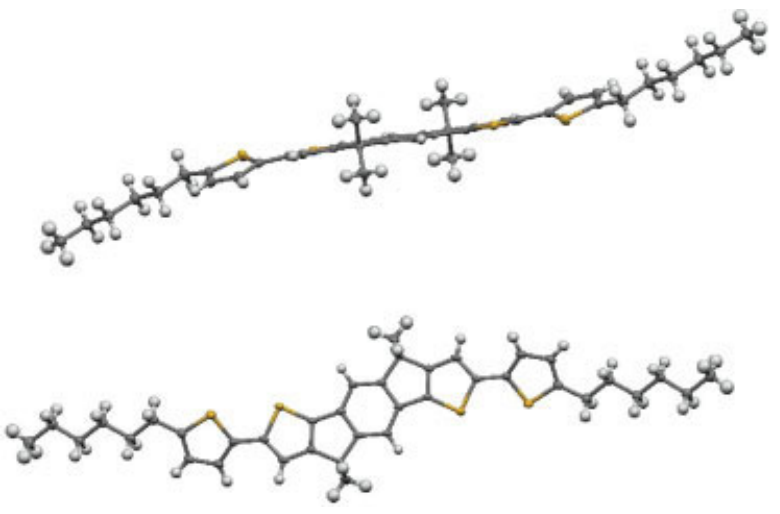

Figure 5. X-ray single crystal structure of model compound 10: View in-plane and perpendicular to the plane of the planarized core segment. 
shift of the absorption and emission maxima with increasing numbers of thiophene building blocks in the corresponding repeat unit. The planar structure of the step-ladder core segment was confirmed by X-ray single crystal analysis of a related model compound.

\section{EXPERIMENTAL}

\section{Materials and Characterization}

Unless otherwise indicated, all reagents were obtained from commercial suppliers and were used without further purification. The solvents used were commercial p.a. quality. The reactions were carried out under argon with the use of standard and Schlenk techniques. The vials for the microwave-assisted reactions were filled in a glove box. ${ }^{1} \mathrm{H}$ - and ${ }^{13} \mathrm{C}-\mathrm{NMR}$ data were obtained on a Bruker ARX 400-spectrometer. The UV-vis and fluorescence spectra were recorded on a Jasco V-550 spectrophotometer and a Varian-Cary Eclipse photoluminescence spectrometer, respectively. Gel permeation chromatographic analysis (GPC) utilized PS-columns (two columns, $5 \mu \mathrm{m}$ gel, pore widths mixed bed linear) connected with UV/vis and RI detection. All GPC analyses were performed on solutions of the polymers in THF at $30{ }^{\circ} \mathrm{C}$ (concentration of the polymer: about $1.5 \mathrm{~g} /$ L). The calibration was based on polystyrene standards with narrow molecular weight distribution. Microwave-assisted syntheses were performed using a CEM Discover microwave system. The monomers $1,{ }^{9} \mathbf{2},{ }^{33} \mathbf{3},{ }^{33}$ and $\mathbf{5}^{29}$ have been synthesized according to literature procedures.

\section{4',4"-Didecyl-2,5-bis(5'-bromothien-2'-yl) terephthalophenone (4)}

a. 1,4-Bis(4,4'-decyl-benzoyl)-2,5-dibromobenzene $(2.0 \mathrm{~g}, 2.76 \mathrm{mmol})$, 2-(tributyl-stannyl)thiophene $(2.36 \mathrm{~g}, 6.34 \mathrm{mmol})$, potassium fluoride $(1.6 \mathrm{~g}$, $27.6 \mathrm{mmol}$ ), and bis(triphenyl-phosphine)-palladium(II)chloride (194 mg, $10 \mathrm{~mol} \%$ ) were mixed in a Schlenk tube under argon atmosphere. THF $(50 \mathrm{~mL})$ was added and the reaction mixture was stirred for 2 days at $90{ }^{\circ} \mathrm{C}$. Afterwards the reaction mixture was extracted with a mixture of water and chloroform. The organic layer was extensively washed with water, dried with $\mathrm{Na}_{2} \mathrm{SO}_{4}$ and the solvent was removed in vacuo. The crude product was purified by column chromatography on silica (hexane/ethyl acetate:99/1 $\mathrm{v}: \mathrm{v})$ and recrystallized from ethanol to give $1.16 \mathrm{~g}$ (58\%) of white crystals.

${ }^{1} \mathrm{H}-\mathrm{NMR}\left(400 \mathrm{MHz}, \mathrm{CDCl}_{3}\right): \delta[\mathrm{ppm}]=7.70(\mathrm{~d}$, $4 \mathrm{H}, \mathrm{J}=8.2 \mathrm{~Hz}), 7.61(\mathrm{~s}, 2 \mathrm{H}), 7.18(\mathrm{~s}, 2 \mathrm{H}), 7.16(\mathrm{~d}$, $4 \mathrm{H}, \mathrm{J}=7.9 \mathrm{~Hz}), 7.00(\mathrm{~d}, 2 \mathrm{H}, \mathrm{J}=3.5 \mathrm{~Hz}), 6.84(\mathrm{dd}$, $2 \mathrm{H}, \mathrm{J}=3.7 \mathrm{~Hz}, \mathrm{~J}=5.0 \mathrm{~Hz}), 2.60(\mathrm{~m}, 4 \mathrm{H}), 1.65(\mathrm{~m}$, $8 \mathrm{H}), 1.36(\mathrm{~m}, 24 \mathrm{H}), 0.93(\mathrm{t}, 6 \mathrm{H}, \mathrm{J}=7.3 \mathrm{~Hz}) .{ }^{13} \mathrm{C}-$ $\mathrm{NMR}\left(100 \mathrm{MHz}, \mathrm{CDCl}_{3}\right): \delta[\mathrm{ppm}]=197.3,149.5$, $140.4,140.0,134.2,131.8,130.1,129.4,128.5$, $127.9,127.6,126.7,36.0,31.8,30.9,29.5,29.5$, 29.4, 29.2, 29.1, 22.6, 13.5. FT-mass: $\mathrm{m} / z$ (calc) $=$ 730.5 (731.1) Anal. Calcd. for $\mathrm{C}_{48} \mathrm{H}_{58} \mathrm{O}_{2} \mathrm{~S}_{2}$ : C, 78.86; H, 8.00; S, 8.77. Found: C, 78.45; H, 7.70; S, 8.79.

b. A solution of $4^{\prime}, 4^{\prime \prime}$-didecyl-2,5-bis(2'-thienyl)terephthalophenone $(1.0 \mathrm{~g}, 1.4 \mathrm{mmol})$ in DMF $(25 \mathrm{~mL})$ was protected from light and cooled down to $-20{ }^{\circ} \mathrm{C}$. To this solution a mixture of NBS $(0.61 \mathrm{~g}, 3.4 \mathrm{mmol}, 2.5 \mathrm{eq})$ in $\mathrm{DMF}(25 \mathrm{~mL})$ was added dropwise. The mixture was stirred at $-20{ }^{\circ} \mathrm{C}$ for $30 \mathrm{~min}$, and then allowed to warm up to room temperature. The mixture was stirred for another $8 \mathrm{~h}$ at room temperature, and then poured onto ice and extracted with dichloromethane. The combined organic layers were dried over $\mathrm{Na}_{2} \mathrm{SO}_{4}$. Afterwards the solvents were removed in vacuo. The crude product was purified by column chromatography on silica (hexane/ ethyl acetate: 90/10 v:v) and recrystallized from ethanol. Yield: $700 \mathrm{mg}$.

${ }^{1} \mathrm{H}-\mathrm{NMR}\left(400 \mathrm{MHz}, \mathrm{C}_{2} \mathrm{D}_{2} \mathrm{Cl}_{4}\right): \delta[\mathrm{ppm}]=7.61$ $(\mathrm{d}, 4 \mathrm{H}, \mathrm{J}=8.2 \mathrm{~Hz}), 7.44(\mathrm{~s}, 2 \mathrm{H}), 7.14(\mathrm{~m}, 4 \mathrm{H}), 6.77$ (d, $2 \mathrm{H}, \mathrm{J}=3.8 \mathrm{~Hz}), 6.67(\mathrm{~d}, 2 \mathrm{H}, \mathrm{J}=3.9 \mathrm{~Hz}), 2.56$ (m, 4H), $1.53(\mathrm{~s}, 8 \mathrm{H}), 1.19(\mathrm{~m}, 24 \mathrm{H}), 0.80(\mathrm{t}, 6 \mathrm{H}, \mathrm{J}$ $=6.8 \mathrm{~Hz}) .{ }^{13} \mathrm{C}-\mathrm{NMR}\left(100 \mathrm{MHz}, \mathrm{C}_{2} \mathrm{D}_{2} \mathrm{Cl}_{4}\right): \delta[\mathrm{ppm}]$ $=197.5,150.0,140.5,140.1,134.3,132.1,130.4$, $129.8,128.9,128.2,128.1,127.2,36.3,32.1,31.1$, 29.8, 29.8, 29.7, 29.6, 29.5, 23.0, 14.5. FT-mass: $\mathrm{m} / z$ (calc) $=887.6$ (888.9). FTIR (neat): $v\left[\mathrm{~cm}^{-1}\right]$ $=2920,2850,1653,1603,1570,1466,1432,1415$, $1375,1310,1282,1239,1178,1145,1119,1078$, 997, 963, 921, 894, 846, 808, 757, 718, 699. Anal. Calcd. for $\mathrm{C}_{48} \mathrm{H}_{56} \mathrm{Br}_{2} \mathrm{O}_{2} \mathrm{~S}_{2}$ : C, 64.84; $\mathrm{H}, 6.35 ; \mathrm{S}$, 7.21. Found: C, 64.76; H, 6.13; S, 7.11.

\section{2,5-Bis(5-hexyl-2, 2'-bithiophene)-5'- yldimethylterephthalate (8)}

A 250-mL two-necked round-bottom flask was charged with 2,5-dibromo-dimethylterephthalate $(1.50 \mathrm{~g}, 4.25 \mathrm{mmol})$, potassium carbonate $(2.9 \mathrm{~g}$, $8.5 \mathrm{mmol}, 4$ equiv.), $\mathrm{Pd}(\mathrm{PPh} 3) 4$ (0.49 g, 10\%), THF $(60 \mathrm{~mL})$, and water $(20 \mathrm{~mL}) .5$-Hexyl-5' - (4,4,5,5-tetramethyl-1,3,2-dioxaborolan-2-yl)-2,2'-bithiophene 
(4 g, $10.6 \mathrm{mmol}, 2.5$ equiv.) was dissolved in degassed THF $(20 \mathrm{~mL})$ and added dropwise to the solution via a syringe. The solution was refluxed for $24 \mathrm{~h}$. The reaction mixture was diluted with chloroform and washed with aqueous $2 \mathrm{~N} \mathrm{HCl}$, saturated aqueous $\mathrm{NaHCO}_{3}$ and NaEDTA solutions and brine. The organic phase was dried over $\mathrm{Na}_{2} \mathrm{SO}_{4}$ and the solvent removed in vacuo. The crude product was purified by column chromatography on silica (Hex/EA:85/15 v:v) and recrystallized from ethanol. Yield: $76 \%$.

${ }^{1} \mathrm{H}-\mathrm{NMR}\left(400 \mathrm{MHz}, \mathrm{CDCl}_{3}\right): \delta[\mathrm{ppm}]=7.72(\mathrm{~s}$, $2 \mathrm{H}), 7.01(\mathrm{~d}, 2 \mathrm{H}, \mathrm{J}=3.7 \mathrm{~Hz}), 6.96(\mathrm{~d}, 2 \mathrm{H}, \mathrm{J}=3.5$ $\mathrm{Hz}), 6.92(\mathrm{~d}, 2 \mathrm{H}, \mathrm{J}=3.7 \mathrm{~Hz}), 6.64(\mathrm{~d}, 2 \mathrm{H}, \mathrm{J}=3.5$ $\mathrm{Hz}), 2.73(\mathrm{t}, 4 \mathrm{H}, \mathrm{J}=7.6 \mathrm{~Hz}), 1.64-1.50(\mathrm{~m}, 4 \mathrm{H})$, $1.33-1.29(\mathrm{~m}, 1 \mathrm{H}), 1.27-1.18(\mathrm{~m}, 12 \mathrm{H}), 0.83(\mathrm{t}$, $6 \mathrm{H}, \mathrm{J}=7.0 \mathrm{~Hz}) \cdot{ }^{13} \mathrm{C}-\mathrm{NMR}\left(100 \mathrm{MHz}, \mathrm{CDCl}_{3}\right)$ : $\delta[\mathrm{ppm}]=168.3,146.4,139.6,138.3,134.3,133.5$, $132.9,131.8,128.1,125.2,124.1,123.7,53.1,31.8$, 31.8, 30.4, 29.0, 22.8, 14.4. FT-mass: $\mathrm{m} / z$ (calc) $=$ 690,4 (691) UV/vis $\left(\mathrm{CHCl}_{3}\right): \lambda_{\max }[\mathrm{nm}]=384$. Anal. Calcd. for $\mathrm{C}_{38} \mathrm{H}_{42} \mathrm{O}_{4} \mathrm{~S}_{4}: \mathrm{C}, 66.05 ; \mathrm{H}, 6.13 ; \mathrm{S}$, 18.56. Found: C, 65.79; H, 5.83; S, 18.09 .

\section{Step-Ladder Model Compound (10)}

A 40-fold excess of MeLi ( $7 \mathrm{~mL}, 11.2 \mathrm{mmol}, 1.6 \mathrm{M}$ ) was added to a solution of the previously synthesized diketone 8 (1.4 g, $0.2 \mathrm{mmol}$ ) in toluene $(30 \mathrm{~mL})$ at room temperature and stirred for $30 \mathrm{~min}$. Afterwards THF $(20 \mathrm{~mL})$ was added and the mixture stirred for additional $12 \mathrm{~h}$. The reaction was stopped with ethanol, chloroform $(100 \mathrm{~mL})$ added, and the solution washed with aqueous $2 \mathrm{~N} \mathrm{HCl}$ and brine. The organic phase was dried over $\mathrm{Na}_{2} \mathrm{SO}_{4}$ and the solvent removed in vacuo. The crude product was dissolved in dichloromethane $(30 \mathrm{~mL})$ and treated with an excess of boron trifluoride etherate $(4 \mathrm{~mL}, 31.8$ $\mathrm{mmol})$. The solution was stirred for $3 \mathrm{~h}$, and then a mixture of ethanol/water (2:1) added. The organic layer was diluted with chloroform and extracted several times with water. The organic phase was dried over $\mathrm{Na}_{2} \mathrm{SO}_{4}$ and the solvent removed in vacuo. The residue was purified by column chromatography on silica (Hex/EA:80/20 $\mathrm{v:v)}$ and recrystallized from ethanol. Yield: $78 \%$.

${ }^{1} \mathrm{H}-\mathrm{NMR}\left(400 \mathrm{MHz}, \mathrm{C}_{2} \mathrm{D}_{2} \mathrm{Cl}_{4}\right): \delta$ [ppm] $=7.50$ $(\mathrm{d}, 2 \mathrm{H}, \mathrm{J}=3.7 \mathrm{~Hz})), 7.25(\mathrm{~s}, 2 \mathrm{H}), 6.98(\mathrm{~s}, 2 \mathrm{H}), 6.63$ $(\mathrm{d}, 2 \mathrm{H}, \mathrm{J}=3.9 \mathrm{~Hz}), 2.72(\mathrm{~m}, 12 \mathrm{H}), 1.66-1.57(\mathrm{~m}$, $4 \mathrm{H}, \mathrm{J}=7.6 \mathrm{~Hz}), 1.52-1.50(\mathrm{~m}, 4 \mathrm{H}), 1.35-1.21(\mathrm{~m}$, $12 \mathrm{H}), 0.82(\mathrm{t}, 6 \mathrm{H}, \mathrm{J}=6.8 \mathrm{~Hz}) .{ }^{13} \mathrm{C}-\mathrm{NMR}(100$ $\left.\mathrm{MHz}, \mathrm{C}_{2} \mathrm{D}_{2} \mathrm{Cl}_{4}\right): \delta[\mathrm{ppm}]=159.1,155.7,145.4$, $140.0,138.7,136.0,134.3,125.0,123.0,117.1$,
113.1, 45.9, 31.7, 31.6, 30.4, 28.9, 26.4, 22.7, 14.2 . FD-mass: $m / z$ (calc.) $=654.8$ (655.1). UV/vis $\left(\mathrm{CHCl}_{3}\right): \lambda_{\max }[\mathrm{nm}]=425,444$ (shoulder). Anal. Calcd. for $\mathrm{C}_{40} \mathrm{H}_{46} \mathrm{~S}_{4}$ : C, 73.34; H, 7.08; S, 19.58. Found: C, 73.04; H, 6.55; S, 19.33 .

\section{General Procedure for Microwave-Assisted Stille-Type Polymerizations}

Equimolar amounts of the bis(trimethylstannyl) oligothiophene and $4^{\prime}, 4^{\prime \prime}$-didecyl-2,5-bis(5'-bromothien-2'-yl)terephthalophenone (15), 10 equiv. of potassium fluoride, and $10 \mathrm{~mol} \% \mathrm{PdCl}_{2}$ (dppf) were mixed in a sealed $10 \mathrm{~mL}$ vial under glove box conditions. Dry toluene $(2 \mathrm{~mL})$ and dry DMF $(1 \mathrm{~mL})$ were added and the solutions irradiated with microwaves $\left(300 \mathrm{~W}, 110{ }^{\circ} \mathrm{C}\right)$ for $15 \mathrm{~min}$. The reaction mixture was diluted with chloroform and washed with aqueous $2 \mathrm{~N} \mathrm{HCl}$, saturated aqueous $\mathrm{NaHCO}_{3}$ and NaEDTA solutions and brine. The organic phase was dried over $\mathrm{Na}_{2} \mathrm{SO}_{4}$ and the solvent removed in vacuo. The residue was dissolved in chloroform, reprecipitated into methanol, filtered, and dried.

\section{Synthesis of Polyketone PK1}

Yield: $44 \%$. GPC (vs. polystyrene standards in THF) $M_{\mathrm{n}}=10,400 \mathrm{~g} / \mathrm{mol}, M_{\mathrm{w}} / M_{\mathrm{n}}=2.8$.

${ }^{1} \mathrm{H}-\mathrm{NMR}\left(400 \mathrm{MHz}, \mathrm{C}_{2} \mathrm{D}_{2} \mathrm{Cl}_{4}\right): \delta[\mathrm{ppm}]=7.67-$ $7.61(\mathrm{~m}, 4 \mathrm{H}), 7.51-7.48(\mathrm{bs}, 2 \mathrm{H}), 7.17-7.11(\mathrm{~m}$, $4 \mathrm{H}), 6.86-6.75(\mathrm{~m}, 4 \mathrm{H}), 2.61-2.53(\mathrm{~m}, 4 \mathrm{H}), 1.59$ $1.49(\mathrm{~m}, 8 \mathrm{H}), 1.29-1.17(\mathrm{~m}, 24 \mathrm{H}), 0.87-0.79(\mathrm{~m}$, $6 \mathrm{H}) .{ }^{13} \mathrm{C}-\mathrm{NMR}\left(100 \mathrm{MHz}, \mathrm{C}_{2} \mathrm{D}_{2} \mathrm{Cl}_{4}\right): \delta$ [ppm] $=$ $196.7,149.9,140.4,139.5,138.3,134.5,131.5$, $130.3,129.5,129.0,128.8,124.9,36.2,32.0,30.8$, $29.7,29.6,29.5,29.4,29.3,22.8,14.2$. UV/vis $\left(\mathrm{CHCl}_{3}\right): \lambda_{\max }[\mathrm{nm}]=492$. FTIR (neat): $v\left[\mathrm{~cm}^{-1}\right]=$ 2922, 2851, $1659(\mathrm{C}=\mathrm{O}), 1603,1572,1529,1485$, $1462,1414,1371,1309,1279,1244,1178,1146$, 1119, 1068, 1019, 984, 928, 893, 849. Anal. Calcd. for $\mathrm{C}_{48} \mathrm{H}_{56} \mathrm{O}_{2} \mathrm{~S}_{2}$ : C, 79.07; H, 7.74; S, 8.80. Found: C, 78.99; H, 7.54; S, 8.49.

\section{Synthesis of Polyketone PK2}

Yield: 47\%. GPC (vs. polystyrene standards in THF) $M_{\mathrm{n}}=14,800 \mathrm{~g} / \mathrm{mol}, M_{\mathrm{w}} / M_{\mathrm{n}}=3.6$. ${ }^{1} \mathrm{H}-\mathrm{NMR}\left(400 \mathrm{MHz}, \mathrm{C}_{2} \mathrm{D}_{2} \mathrm{Cl}_{4}\right): \delta[\mathrm{ppm}]=7.66$ $7.59(\mathrm{~m}, 4 \mathrm{H}), 7.49-7.44(\mathrm{bs}, 2 \mathrm{H}), 7.12-7.01(\mathrm{~m}$, $6 \mathrm{H}), 6.82-6.74(\mathrm{~m}, 4 \mathrm{H}), 2.58-2.51(\mathrm{~m}, 4 \mathrm{H}), 1.62$ $1.47(\mathrm{~m}, 8 \mathrm{H}), 1.33-1.16(\mathrm{~m}, 24 \mathrm{H}), 0.88-0.79(\mathrm{~m}$, $6 \mathrm{H}) .{ }^{13} \mathrm{C}-\mathrm{NMR}\left(100 \mathrm{MHz}, \mathrm{C}_{2} \mathrm{D}_{2} \mathrm{Cl}_{4}\right): \delta[\mathrm{ppm}]=$ $194.2,149.1,140.4,140.2,138.0,134.6,134.5$, 
$131.5,130.1,129.4,129.2,129.1,128.6,124.5$, 36.2 , 32.1, 30.5, 29.7, 29.6, 29.5, 29.4, 29.2, 23.1, 14.3. UV/VIS $\left(\mathrm{CHCl}_{3}\right): \lambda_{\max }[\mathrm{nm}]=494$. FTIR (neat): $v\left[\mathrm{~cm}^{-1}\right]=2922,2849,1663(\mathrm{C}=\mathrm{O}), 1599$, $1575,1538,1455,1416,1371,1309,1279,1256$, 1173, 1133, 1075, 990, 927. Anal. Calcd. for $\mathrm{C}_{52} \mathrm{H}_{58} \mathrm{O}_{2} \mathrm{~S}_{3}: \mathrm{C}, 76.99 ; \mathrm{H}, 7.21 ; \mathrm{S}, 11.86$. Found: C, 76.88; H, 6.98; S, 11.42 .

\section{Synthesis of Polyketone PK3}

Yield: 52\%. GPC (versus polystyrene standards in THF) $M_{\mathrm{n}}=12,600 \mathrm{~g} / \mathrm{mol}, M_{\mathrm{w}} / M_{\mathrm{n}}=3.2$.

${ }^{1} \mathrm{H}-\mathrm{NMR}\left(400 \mathrm{MHz}, \mathrm{C}_{2} \mathrm{D}_{2} \mathrm{Cl}_{4}\right): \delta[\mathrm{ppm}]=7.69-$ $7.60(\mathrm{~m}, 4 \mathrm{H}), 7.56-7.44(\mathrm{~m}, 2 \mathrm{H}), 7.18-7.10(\mathrm{~m}$, 4H), 7.04-6.71 (m, 8H), 2.59-2.51 (m, 4H), 1.58$1.43(\mathrm{~m}, 8 \mathrm{H}), 1.26-1.11(\mathrm{~m}, 24 \mathrm{H}), 0.85-0.75(\mathrm{~m}$, 6H). ${ }^{13} \mathrm{C}-\mathrm{NMR}\left(100 \mathrm{MHz}, \mathrm{C}_{2} \mathrm{D}_{2} \mathrm{Cl}_{4}\right): \delta[\mathrm{ppm}]=$ $196.9,150.0,140.5,135.0,134.6,131.8,131.7$, $130.3,129.1,128.9,127.9,127.6,125.0,124.9$, $124.8,124.7,36.2,32.0,30.9,29.8,29.7,29.6$, 29.5, 29.4, 22.8, 14.2. UV/vis $\left(\mathrm{CHCl}_{3}\right): \lambda_{\max }[\mathrm{nm}]=$ 495. FTIR (neat): $v\left[\mathrm{~cm}^{-1}\right]=2919,2850,1661$ $(\mathrm{C}=\mathrm{O}), 1603$, 1489, 1456, 1414, 1337, 1280, 1251, 1178, 1146, 1101, 1067, 926, 893, 850, 788. Anal. Calcd. for $\mathrm{C}_{56} \mathrm{H}_{60} \mathrm{O}_{2} \mathrm{~S}_{4}$ : C, 75.29; H, 6.77; S, 14.36. Found: C, 75.02; H, 6.55; S, 13.98 .

\section{Synthesis of Polyketone PK4}

The herein utilized method was slightly modified with respect to the general procedure: 1,5-dibromo2,5-bis(4-tert-butyl-benzoyl)naphthalene $(100 \mathrm{mg}$, $0.16 \mathrm{mmol}$ ), 5,5'-bis(trimethylstannyl)-2,2'-bithiophene $(81.1 \mathrm{mg}, 0.16 \mathrm{mmol})$, potassium fluoride (95.8 mg, $1.6 \mathrm{mmol}$ ), and 1,1-bis(diphenylphosphino)ferrocene-dichloropalladium(II) (12.1 $\mathrm{mg}$, $10 \mathrm{~mol} \mathrm{\%}$ ) were transferred into a $10 \mathrm{~mL}$ microwave vial. Afterwards the microwave vial was sealed, evacuated, and flushed with argon. Toluene $(2 \mathrm{~mL})$ and $1 \mathrm{~mL}$ of DMF were added via a syringe and the mixture irradiated with microwaves $\left(300 \mathrm{~W}, 120{ }^{\circ} \mathrm{C}\right)$ for $12 \mathrm{~min}$ until black palladium metal precipitated out. The mixture was filtered to remove the metallic palladium, diluted with chloroform, and washed with aqueous $2 \mathrm{~N} \mathrm{HCl}$, saturated aqueous $\mathrm{NaHCO}_{3}$ and NaEDTA solutions and brine. The organic phase was dried over $\mathrm{Na}_{2} \mathrm{SO}_{4}$ and the solvent removed in vacuo. The residue was dissolved in chloroform, reprecipitated into methanol, filtered and dried. Yield: 49\%. GPC (vs. polystyrene standards in THF) $M_{\mathrm{n}}=12,800 \mathrm{~g} / \mathrm{mol}, M_{\mathrm{w}} / M_{\mathrm{n}}=2.4$.
${ }^{1} \mathrm{H}-\mathrm{NMR}\left(\mathrm{C}_{2} \mathrm{D}_{2} \mathrm{Cl}_{4}, 400 \mathrm{MHz}\right): \delta[\mathrm{ppm}]=8.20$ $8.12(\mathrm{~m}, 2 \mathrm{H}), 7.57-7.52(\mathrm{~m}, 4 \mathrm{H}), 7.33-7.27(\mathrm{~m}$, $4 \mathrm{H}), 6.92-6.88(\mathrm{~m}, 2 \mathrm{H}), 6.87-6.83(\mathrm{~m}, 2 \mathrm{H}), 1.27-$ $1.21(\mathrm{~m}, 18 \mathrm{H}) .{ }^{13} \mathrm{C}-\mathrm{NMR}\left(\mathrm{C}_{2} \mathrm{D}_{2} \mathrm{Cl}_{4}, 100 \mathrm{MHz}\right)$ : $\delta[\mathrm{ppm}]=197.4,157.3,140.3,139.1,136.7$, $135.1,133.9,131.5,130.0,128.0,125.9,125.3$, 124.2, 123.9, 35.2, 31.2. FTIR (neat): $v\left[\mathrm{~cm}^{-1}\right]=$ 2925, 2852, 1671, 1603, 1461, 1408, 1362, 1332, 1259, 1193, 1164, 1108, 1026, 976, 866, 847, 794, 772, 719, 701. Anal. Calcd. for $\mathrm{C}_{40} \mathrm{H}_{34} \mathrm{O}_{2} \mathrm{~S}_{2}$ : C, 78.65; H, 5.61; S, 10.50; Found C, 78.19; H, 6.23; S, 9.96 .

\section{General Procedure for the Cyclization Sequence}

A 40-fold excess of MeLi (3.5 mL, $5.6 \mathrm{mmol}$, $1.6 \mathrm{M}$ ) was added at room temperature to a solution of the previously synthesized diketo polymer $(0.1 \mathrm{mmol})$ in toluene $(30 \mathrm{~mL})$ and stirred for $30 \mathrm{~min}$. Afterwards THF $(20 \mathrm{~mL})$ was added and the mixture stirred at room temperature for additional $12 \mathrm{~h}$. The reaction was quenched with ethanol, chloroform added, and the solution was washed with aqueous $2 \mathrm{~N} \mathrm{HCl}$ and brine. The organic phase was dried over $\mathrm{Na}_{2} \mathrm{SO}_{4}$ and the solvent removed in vacuo. The crude product was dissolved in dichloromethane $(30 \mathrm{~mL})$ and treated with an excess of borontrifluoride etherate $(2 \mathrm{~mL}$, $15.9 \mathrm{mmol})$. The solution was stirred for $3 \mathrm{~h}$ and then a mixture of ethanol/water (2:1) was added. The organic layer was diluted with chloroform and extracted several times with water. The organic phase was dried over $\mathrm{Na}_{2} \mathrm{SO}_{4}$ and the solvent removed in vacuo. The residue was dissolved in chloroform and precipitated into methanol to give the cyclized step-ladder copolymers.

\section{Synthesis of the Step-Ladder Copolymer SL1}

Yield: $76 \%$. GPC (vs. polystyrene standards in THF) $M_{\mathrm{n}}=12,000 \mathrm{~g} / \mathrm{mol}, M_{\mathrm{w}} / M_{\mathrm{n}}=2.0$.

${ }^{1} \mathrm{H}-\mathrm{NMR}\left(400 \mathrm{MHz}, \mathrm{C}_{2} \mathrm{D}_{2} \mathrm{Cl}_{4}\right): \delta[\mathrm{ppm}]=7.61$ $(\mathrm{d}, 4 \mathrm{H}, \mathrm{J}=8 \mathrm{~Hz}), 7.45(\mathrm{~s}, 2 \mathrm{H}), 7.11(\mathrm{~d}, 4 \mathrm{H}, \mathrm{J}=$ $8 \mathrm{~Hz}), 6.76$ (bs, $2 \mathrm{H}), 2.58-2.44(\mathrm{~m}, 4 \mathrm{H}), 1.88-1.80$ (bs, 6H, CH3 bridge), 1.52-1.48 (m, 8H), 1.21-1.11 (m, 24H), 0.81-0.75 (m, 6H). ${ }^{13} \mathrm{C}-\mathrm{NMR}(100 \mathrm{MHz}$, $\left.\mathrm{C}_{2} \mathrm{D}_{2} \mathrm{Cl}_{4}\right): \delta[\mathrm{ppm}]=140.9,140.0,136.9,136.3$, $133.9,133.0130 .9,128.8,128.2,126.1,125.8$, 53.2, 36.1, 32.2, 31.0, 29.7, 29.6, 29.5, 29.4, 29.3, 23.0, 14.2, 13.5. UV/vis $\left(\mathrm{CHCl}_{3}\right): \lambda_{\max }(\mathrm{nm})=492$. FTIR (neat): $v\left(\mathrm{~cm}^{-1}\right)=2920,2850,1510,1455$, $1414,1374,1322,1242,1187,1123,1059,1018$, $990,960,871,822,720,698,674,658$. Anal. 
Calcd. for $\mathrm{C}_{50} \mathrm{H}_{60} \mathrm{~S}_{2}$ : C, 82.82; H, 8.34; S, 8.84 . Found: C, 82.60; H, 7.99; S, 8.61.

\section{Synthesis of the Step-Ladder Copolymer SL2}

Yield: $71 \%$. GPC (vs. polystyrene standards in THF) $M_{\mathrm{n}}=16,200 \mathrm{~g} / \mathrm{mol}, \quad M_{\mathrm{w}} / M_{\mathrm{n}}=2.9$. ${ }^{1} \mathrm{H}-\mathrm{NMR}\left(400 \mathrm{MHz}, \mathrm{C}_{2} \mathrm{D}_{2} \mathrm{Cl}_{4}\right): \delta$ [ppm] $=7.25-$ $7.12(\mathrm{~m}, 6 \mathrm{H}), 7.08-6.85(\mathrm{~m}, 8 \mathrm{H}), 2.57-2.42(\mathrm{~m}$, $4 \mathrm{H}), 1.95-1.75$ (m, $6 \mathrm{H}, \mathrm{CH} 3$ bridge), $1.65-1.45(\mathrm{~m}$, $8 \mathrm{H}), 1.35-1.05(\mathrm{~m}, 24 \mathrm{H}), 0.90-0.74(\mathrm{~m}, 6 \mathrm{H}) .{ }^{13} \mathrm{C}-$ $\operatorname{NMR}\left(100 \mathrm{MHz}, \mathrm{C}_{2} \mathrm{D}_{2} \mathrm{Cl}_{4}\right): \delta[\mathrm{ppm}]=140.2,138.4$, $137.1,136.5,136.1,133.3,130.7,129.8,129.4$, 128.7, 128.2, 125.0, 124.9, 54.1, 36.2, 32.0, 31.1, 29.7, 29.6, 29.5, 29.4, 29.3, 22.9, 14.2, 13.5. UV/vis $\left(\mathrm{CHCl}_{3}\right): \lambda_{\max }[\mathrm{nm}]=508$. FTIR (neat): $v\left[\mathrm{~cm}^{-1}\right]=$ 2922, 2851, 1606, 1511, 1455, 1410, 1374, 1293, 1260, 1170, 1064, 1018, 904, 827, 790, 716, 692. Anal. Calcd. for $\mathrm{C}_{54} \mathrm{H}_{62} \mathrm{~S}_{3}$ : C, 80.34; H, 7.74; S, 11.92. Found: C, 79.84; H, 7.26; S, 11.72.

\section{Synthesis of the Step-Ladder Copolymer SL3}

Yield: 72\%. GPC (vs. polystyrene standards in THF) $M_{\mathrm{n}}=14,200 \mathrm{~g} / \mathrm{mol}, M_{\mathrm{w}} / M_{\mathrm{n}}=3.1$. ${ }^{1} \mathrm{H}-\mathrm{NMR}\left(400 \mathrm{MHz}, \mathrm{C}_{2} \mathrm{D}_{2} \mathrm{Cl}_{4}\right): \delta$ [ppm] $=7.23-$ $7.18(\mathrm{~m}, 2 \mathrm{H}), 7.18-7.11(\mathrm{~m}, 4 \mathrm{H}), 7.07-6.97(\mathrm{~m}$, $6 \mathrm{H}), 6.97-6.93(\mathrm{~m}, 4 \mathrm{H}), 2.56-2.44(\mathrm{~m}, 4 \mathrm{H}), 1.90-$ 1.77 (m, 6H, CH3 bridge), 1.58-1.39 (m, 8H), 1.33$1.06(\mathrm{~m}, 24 \mathrm{H}), 0.87-0.74(\mathrm{~m}, 6 \mathrm{H}) .{ }^{13} \mathrm{C}-\mathrm{NMR}(100$ $\left.\mathrm{MHz}, \mathrm{C}_{2} \mathrm{D}_{2} \mathrm{Cl}_{4}\right): \delta[\mathrm{ppm}]=140.4,138.2,137.6$, $137.0,136.4,136.5,133.7,133.6,130.4,129.9$, $128.8,128.1,125.4,125.1,124.9,56.3,36.1,32.1$, 31.4, 29.7, 29.6, 29.5, 29.4, 29.3, 22.8, 14.2, 13.6 . $\mathrm{UV} /$ vis $\left(\mathrm{CHCl}_{3}\right): \lambda_{\max }(\mathrm{nm})=509$. FTIR (neat): $v$ $\left[\mathrm{cm}^{-1}\right]=2920,2850,1510,1455,1414,1374,1322$, 1187, 1171, 1122, 1100, 1058, 1018, 871, 825, 787. Anal. Calcd. for $\mathrm{C}_{58} \mathrm{H}_{64} \mathrm{~S}_{4}$ : C, 78.33; H, 7.25; S, 14.42. Found: C, 77.82; H, 6.98; S, 14.11 .

\section{Synthesis of the Step-Ladder Copolymer SL4}

Yield: $82 \%$. GPC (vs. polystyrene standards in THF) $M_{\mathrm{n}}=13,500 \mathrm{~g} / \mathrm{mol}, M_{\mathrm{w}} / M_{\mathrm{n}}=2.1$. ${ }^{1} \mathrm{H}-\mathrm{NMR}\left(\mathrm{C}_{2} \mathrm{D}_{2} \mathrm{Cl}_{4}, 400 \mathrm{MHz}\right): \delta[\mathrm{ppm}]=8.01-$ $7.94(\mathrm{~m}, 4 \mathrm{H}), 7.92(\mathrm{~s}, 2 \mathrm{H}), 7.56-7.49(\mathrm{~m}, 4 \mathrm{H})$, 7.25-7.15 (m, 4H), 1.99-1.90 (m, 6H, $\mathrm{CH}_{3}$ bridge), $1.24(\mathrm{~s}, 18 \mathrm{H}) .{ }^{13} \mathrm{C}-\mathrm{NMR}\left(100 \mathrm{MHz}, \mathrm{C}_{2} \mathrm{D}_{2} \mathrm{Cl}_{4}\right): \delta$ $[\mathrm{ppm}]=149.1,140.2,134.4,133.8,133.6,132.8$, $131.0,127.7,126.1,126.0125 .8,125.7,125.5$, $55.4,34.5,31.2,13.2 . \mathrm{UV} / \mathrm{vis}\left(\mathrm{CHCl}_{3}\right): \lambda_{\max }[\mathrm{nm}]=$ 485. FT-IR (neat): $v\left[\mathrm{~cm}^{-1}\right]=2959,2924,2862$, $1674,1560,1512,1455,1407,1384,1361,1332$, 1260, 1217, 1200, 1114, 1087, 1061, 1014, 984,
927, 839, 810, 747, 724, 698, 668, 654. Anal. Calcd. for $\mathrm{C}_{42} \mathrm{H}_{38} \mathrm{~S}_{2}$ : C, 83.12; H, 6.31; S, 10.57; Found: C, 83.01; H, 6.22; S, 10.37.

\section{REFERENCES AND NOTES}

1. Kraft, A.; Grimsdale, A. C.; Holmes, A. B. Angew Chem Int Ed 1998, 37, 402-428.

2. Anthony, J. E. Chem Rev 2006, 106, 5028-5048.

3. McGehee, M. D.; Heeger, A. J. Adv Mater 2000, $12,1655-1668$.

4. Dimitrakopoulos, C. D.; Malenfant, P. R. L. Adv Mater 2002, 14, 99-117.

5. Brabec, C. J.; Shaheen, S. E.; Fromherz, T.; Padinger, F.; Hummelen, J. C.; Dhanabalan, A.; Janssen, R. A. J.; Sariciftci, N. S. Synth Met 2001, 121, 1517-1520.

6. Brabec, C. J.; Sariciftci, N. S.; Hummelen, J. C. Adv Funct Mater 2001, 11, 15-26.

7. Sheats, J. R. J Mater Res 1974, 19, 1974-1989.

8. Grimsdale, A. C.; Müllen, K. Macromol Rapid Commun 2007, 28, 1676-1702.

9. Scherf, U.; Müllen, K. Macromol Rapid Commun 1991, 12, 489-497.

10. Pietrangelo, A.; MacLachlan, M. J.; Wolf, M. O.; Patrick, B. O. Org Lett 2007, 9, 3571-3573.

11. Cicoira, F.; Santato, C.; Melucci, M.; Favaretto, L.; Gazzano, M.; Muccini, M.; Barbarella, G. Adv Mater 2006, 18, 169-174.

12. Li, X. C.; Sirringhaus, H.; Garnier, F.; Holmes, A. B.; Moratti, S. C.; Feeder, N.; Clegg, W.; Teat, S. J.; Friend, R. H. J Am Chem Soc 1998, 120, 2206-2207.

13. Takimiya, K.; Kunugi, Y.; Konda, Y.; Niihara, N.; Otsubo, T. J. Am Chem Soc 2004, 126, 5084-5085.

14. Wang, B.; Shen, F.; Lu, P.; Tang, S.; Zhang, W.; Pan, S.; Liu, M.; Liu, L.; Qiu, S.; Ma, Y. J Polym Sci Part A: Polym Chem 2008, 46, 3120-3127.

15. Wex, B.; Kaafarani, B. R.; Schroeder, R.; Majewski, L. A.; Burckel, P.; Grell, M.; Neckers, D. C. J Mater Chem 2006, 16, 1121-1124.

16. Xiao, K.; Liu, Y.; Qi, T.; Zhang, W.; Wang, F.; Gao, J.; Qiu, W.; Ma, Y.; Cui, G.; Chen, S.; Zhan, X.; Yu, G.; Qin, J.; Hu, W.; Zhu, D. J Am Chem Soc 2005, 127, 13281-13286.

17. Liao, L.; Cirpan, A.; Chu, Q.; Karasz, F. E.; Pang, Y. J Polym Sci Part A: Polym Chem 2007, 45, 20482058.

18. Yamamoto, T.; Takimiya, K. J Am Chem Soc 2007, 129, 2224-2225.

19. Li, Y. N.; Wu, Y. L.; Gardner, S.; Ong, B. S. Adv Mater 2005, 17, 849-853.

20. Wu, Y. L.; Li, Y. N.; Gardner, S.; Ong, B. S. J Am Chem Soc 2005, 127, 614-618.

21. Kalinin, A. V.; Reed, M. A.; Norman, B. H.; Snieckus, V. J Org Chem 2003, 68, 5992-5999.

22. Forster, M.; Scherf, U. Macromol Rapid Commun 2000, 21, 810-813.

Journal of Polymer Science: Part A: Polymer Chemistry DOI 10.1002/pola 
23. Chmil, K.; Scherf, U. Makromol Chem Rapid Commun 1993, 14, 217-222.

24. Nehls, B. S.; Fuldner, S.; Preis, E.; Farrell, T.; Scherf, U. Macromolecules 2005, 38, 687-694.

25. Schlüter, A. D. J Polym Sci Part A: Polym Chem 2001, 39, 1533-1556.

26. Scherf, U. J. Mater Chem 1999, 9, 1853-1864.

27. Scherf, U.; Bohnen, A.; Müllen, K. Macromol Chem 1992, 193, 1127-1133.

28. Melucci, M.; Barbarella, G.; Sotgiu, G. J Org Chem 2002, 67, 8877-8884.
29. Preis, E.; Scherf, U. Macromol Rapid Commun 2006, 27, 1105-1109.

30. Sasaki, S.; Yamamoto, T.; Kanbara, T.; Morita, A.; Yamamoto, T. J Polym Sci Part B: Polym Phys 1992, 30, 293-297.

31. Kobashi, M.; Takeuchi, H. Macromolecules 1998, 31, 7272-7278.

32. Chen, S. A.; Lee, S. J Synth Met 1995, 72, 253-260.

33. Furuta, P.; Fréchet, J. M. J. J Am Chem Soc 2003, 125, 13173-13181. 